\title{
(6) OPEN ACCESS \\ National Cancer Institute's leadership role in promoting State and Community Tobacco Control research
}

\author{
Elizabeth M Ginexi, Robert E Vollinger Jr
}

National Cancer Institute, Tobacco Control Research Branch, Bethesda, Maryland, USA

\section{Correspondence to} Dr Elizabeth M Ginexi, National Cancer Institute, Tobacco Control Research Branch, 9609 Medical Center Drive, Room 3E564, MSC 9761, Bethesda 20892-9761, USA; LGinexi@mail.nih.gov

Received 2 May 2016 Accepted 11 May 2016

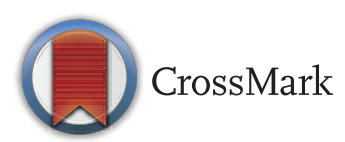

To cite: Ginexi EM, Vollinger RE. Tob Control 2016;25:i4-i5.

\section{ABSTRACT}

The National Cancer Institute (NCI) has been at the vanguard of funding tobacco control research for decades with major efforts such as the Community Intervention Trial for Smoking Cessation (COMMIT) in 1988 and the American Stop Smoking Intervention Study (ASSIST) in 1991, followed by the Tobacco Research Initiative for State and Community Interventions in 1999. Most recently, in 2011, the $\mathrm{NCl}$ launched the State and Community Tobacco Control (SCTC) Research Initiative to address gaps in secondhand smoke policies, tax and pricing policies, mass media countermeasures, community and social norms and tobacco marketing. The initiative supported large scale research projects and time-sensitive ancillary pilot studies in response to expressed needs of state and community partners. This special issue of Tobacco Control showcases exciting findings from the SCTC. In this introductory article, we provide a brief account of $\mathrm{NCl}^{\prime} \mathrm{s}$ historical commitment to promoting research to inform tobacco control policy.

The 1964 Surgeon General's report on Smoking and Health spurred education, programmatic and policy intervention, litigation and social norm changes that revolutionised how Americans view tobacco. Cigarette smoking prevalence among US adults has declined from $42.4 \%$ in 1965 to $16.8 \%$ in 2014. ${ }^{1}$ Tobacco control efforts since 1964 have prevented an estimated 8 million US deaths and extended mean life span by 19-20 years. ${ }^{2}$ Still, tobacco use remains the leading cause of preventable, premature death in the USA, including mortality from lung and other cancers. ${ }^{3}$ High tobacco use persists based on many factors such as income, education and comorbid mental health conditions. For example, in 2014, cigarette smoking was at $15.2 \%$ for people above the federal poverty level versus $26.3 \%$ for those below. ${ }^{3}{ }^{4}$ In addition, while secondhand smoke (SHS) exposure dropped from $50 \%$ among non-smokers in $1999-2000$ to $25 \%$ in 2011-2012, exposure remains high among many groups including poor people and non-smoker African-American adults and children. ${ }^{5}$ These high rates of smoking prevalence and SHS exposure translate into significant inequalities in lung cancer incidence and mortality. ${ }^{6} 7$ Redoubled tobacco control is needed to reverse these disparities and reduce cancer incidence. In particular, sciencebased policy approaches hold great promise to further decrease the health, social and economic burdens of tobacco use, and narrow the observed disparities across subpopulations. ${ }^{3}$
State and community-level tobacco control policies and programmes attempt to change social-environmental contexts, which in turn influence tobacco-related attitudes and behaviours. Policy is effective because of its broad reach, ability to change social norms and because it can be implemented at lower cost than individual interventions. ${ }^{89}$ Policies that increase taxes, establish smoke-free workplaces and restrict marketing are highly effective for reducing tobacco use, and for increasing support for tobacco-free environments. ${ }^{10}$

The National Cancer Institute (NCI) has been at the vanguard of funding tobacco control research with major efforts such as the Community Intervention Trial for Smoking Cessation (COMMIT) in $1988,{ }^{11}$ the American Stop Smoking Intervention Study (ASSIST) in 1991, ${ }^{12} 13$ and the Tobacco Research Initiative for State and Community Interventions in $1999 .{ }^{14}$ In 2011, the NCI launched the State and Community Tobacco Control (SCTC) Research Initiative to address policy research gaps, with large-scale studies and time-sensitive pilot investigations based on state and community needs. ${ }^{15}$ Grantees were also charged with developing effective strategies to disseminate their research findings to a wide array of audiences, including tobacco control programmes, public health practitioners, researchers, and federal, state and local policymakers. A full description of the SCTC Research Initiative is available at http://sctcresearch.org/PublicHome. Over 100 publications and 285 conference presentations have been authored so far, and this special issue of Tobacco Control showcases additional findings.

Return on research investment has been significant, but further inquiry will be critical for continued progress. Consumers are now exposed to and are increasingly using a wider variety of products, including cigars, little cigars and cigarillos, smokeless tobacco products, electronic nicotine delivery systems (ENDS) and waterpipes. ${ }^{16}$ As of March 2016, 4 states and Washington, DC, allow marijuana consumption and 23 States, Guam and Washington, DC, have passed medical marijuana laws. ${ }^{17} 18$ Marijuana and cannabis oil are often combined with cigars, cigarillos and ENDS. ${ }^{19} 20$ Increased alternative product and marijuana use may influence tobacco use patterns, and may also threaten implementation and enforcement of smoke-free policies. Legislated definitions of ENDS may affect whether existing sales, marketing, youth access and taxation laws for cigarettes will apply to ENDS, and thus complicate policy-making. ${ }^{21}$ Synergistic opportunities between local tobacco control and federal regulation are forthcoming. ${ }^{22}$ 
For example, the 2009 Family Smoking Prevention and Tobacco Control Act expanded local governments' ability to curtail tobacco product advertising, and, as a result, states and localities have started implementing innovative strategies such as new community point-of-sale marketing restrictions. ${ }^{23}$ Clearly, future state and community tobacco control policy research will need to adapt in order to study this increasingly complex and dynamic product and policy landscape while also striving to complement Federal regulatory authority.

Contributors EMG and REV are coauthors of this Editorial paper.

Competing interests None declared.

Provenance and peer review Not commissioned; internally peer reviewed.

Open Access This is an Open Access article distributed in accordance with the Creative Commons Attribution Non Commercial (CC BY-NC 4.0) license, which permits others to distribute, remix, adapt, build upon this work non-commercially, and license their derivative works on different terms, provided the original work is properly cited and the use is non-commercial. See: http://creativecommons.org/ licenses/by-nc/4.0/

\section{REFERENCES}

1 Office on Smoking and Health, National Center for Chronic Disease Prevention and Health Promotion. Trends in Current Cigarette Smoking Among High School Students and Adults, U.S., 1965-2014. http://www.cdc.gov/tobacco/data_statistics/ tables/trends/cig_smoking/index.htm

2 Holford TR, Meza R, Warner KE, et al. Tobacco control and the reduction in smoking-related premature deaths in the United States, 1964-2012. JAMA 2014;311:164-71.

3 Department of Health and Human Services. The health consequences of smoking50 years of progress: a report of the surgeon general, 2014. Atlanta, GA: U.S. Department of Health and Human Services, Centers for Disease Control and Prevention, National Center for Chronic Disease Prevention and Health Promotion, Office on Smoking and Health, 2014

4 Jamal A, Homa DM, O'Connor E, et al. Current cigarette smoking among adultsUnited States, 2005-2014. MMWR Morb Mortal Wkly Rep 2015;64:1233-40.

5 Homa DM, Neff LJ, King BA, et al. Vital signs: disparities in nonsmokers' exposure to secondhand smoke-United States, 1999-2012. MMWR Morb Mortal Wkly Rep 2015;64:103-8.

6 Singh GK, Siahpush M. Widening rural-urban disparities in life expectancy, U.S., 1969-2009. Am J Prev Med 2014;46:e19-29.

7 U.S. Cancer Statistics Working Group. United States cancer statistics: 1999-2012. Incidence and mortality web-based report. Atlanta: U.S. Department of Health and
Human Services, Centers for Disease Control and Prevention and National Cancer Institute, 2015. http://www.cdc.gov/uscs

8 Frieden TR. A framework for public health action: the health impact pyramid. Am J Public Health 2010;100:590-5.

9 Cummings KM, Fong GT, Borland R. Environmental influences on tobacco use: evidence from societal and community influences on tobacco use and dependence. Annual Rev Clin Psychol 2009;5:433-58.

10 Centers for Disease Control and Prevention (CDC). Best practices for comprehensive tobacco control programs - 2014. Atlanta: U.S. Department of Health and Human Services, Centers for Disease Control and Prevention, National Center for Chronic Disease Prevention and Health Promotion, Office on Smoking and Health, 2014.

11 National Cancer Institute (NCI). Monograph 6 NCI Monograph 6: community-Based Interventions for Smokers: the COMMIT Field Experience. 1995. http://cancercontrol. cancer.gov/brp/tcrb/monographs/6/index.html

12 National Cancer Institute (NCI). Monograph 16: ASSIST—-shaping the Future of Tobacco Prevention and Control: implementation of American Stop Smoking Intervention Study for Cancer Prevention. 2005. http://cancercontrol.cancer.gov/brp/ tcrb/monographs/16/index.html

13 National Cancer Institute (NCI). Monograph 17: evaluating ASSIST—a Blueprint for Understanding State-level Tobacco Control: evaluation of American Stop Smoking Intervention Study for Cancer Prevention. 2006. http://cancercontrol.cancer.gov/brp/ tcrb/monographs/17/index.html

14 National Cancer Institute (NCI). Tobacco Research Initiative for State and Community Interventions (TRISCI) website. 2012. http://cancercontrol.cancer.gov/ brp/tcrb/scrfa.html (accessed 26 April 2015).

15 Schmitt CL, Lee YO, Curry LE, et al. Research support for effective state and community tobacco control program response to electronic nicotine delivery systems. Tob Control 2014;23(Suppl 3):iii54-7.

16 Agaku IT, King BA, Husten CG, et al. Tobacco product use among adults-U.S., 2012-2013. MMWR Morb Mortal Wkly Rep 2014;63:542-7.

17 NORML State Info. [database online]. http://norml.org/states

18 National Conference of State Legislatures. State medical marijuana laws. 2016. http://www.ncsl.org/research/health/state-medical-marijuana-laws.aspx

19 Delnevo CD, Bover-Manderski MT, Hrywna M. Cigar, marijuana, and blunt use among US adolescents: are we accurately estimating the prevalence of cigar smoking among youth? Prev Med 2011;52:475-6.

20 Morean ME, Kong G, Camenga DR, et al. High school students' use of electronic cigarettes to vaporize cannabis. Pediatrics 2015;136:611-16.

21 Lempert L, Grana R, Glantz S. The importance of product definitions in US e-cigarette laws and regulations. Tob Control 2016;25:e44-51.

22 Ashley DL, Backinger CL, van Bemmel DM, et al. Tobacco regulatory science: research to inform regulatory action at the Food and Drug Administration's Center for Tobacco Products. Nicotine Tob Res 2014;16:1045-9.

23 Tobacco Control Legal Consortium. Point-of sale strategies, a tobacco control guide. Spring, 2014. 